\title{
Relationship between cardiac magnetic resonance imaging parameters and pregnancy outcomes in women post mustard repair: a multi- center study
}

\author{
Laura Jimenez Juan ${ }^{1 *}$, Anne Marie Valente ${ }^{2}$, Bernd J Wintersperger ${ }^{3}$, Candice Silversides $^{4}$, Andrew M Crean ${ }^{3,4}$, \\ Jack M Colman', Elsie T Nguyen ${ }^{3}$, Tal Geva², Rachel M Wald ${ }^{3,4}$
}

From 16th Annual SCMR Scientific Sessions

San Francisco, CA, USA. 31 January - 3 February 2013

\section{Background}

Summary: To examine the relationship between cardiovascular magnetic resonance imaging (CMR) parameters and pregnancy outcomes post Mustard palliation.

Background: Impaired systemic ventricular function and presence of a systemic right ventricle (RV) are associated with adverse events in pregnancy. Women with transposition of the great arteries post atrial switch (Mustard procedure) are at risk of worsening arrhythmia and heart failure antenatally. Contemporary guidelines suggest that women with "more moderate systemic RV dysfunction" should be advised against pregnancy; however a threshold RV ejection fraction (EF) has not been defined as all studies to date have examined RV function using echocardiography alone. The CMR characteristics of women post Mustard palliation undergoing pregnancy and the relationship between CMR parameters and pregnancy outcomes have not yet been described.

\section{Methods}

A total of 17 consecutive women post Mustard procedure seen at 2 tertiary care centers who had undergone CMR within 2 years of pregnancy were included. Parameters of ventricular function were assessed by a single experienced reader using steady-state free-precession cine CMR acquired in the short-axis orientation. Adverse cardiovascular events (sustained arrhythmia, heart failure, stroke, cardiac arrest and/or urgent cardiac intervention), obstetric complications (eclampsia, pre-term labour,

\footnotetext{
${ }^{1}$ Radiology, Sunnybrook Health Sciences Centre, Toronto, ON, Canada

Full list of author information is available at the end of the article
}

hemorrhage) and fetal/neonatal events (stillbirth/death, prematurity, low birthweight, intensive care unit admission) were recorded.

\section{Results}

Demographics and pregnancy outcomes are detailed in table 1 . All women were asymptomatic (NYHA 1) at baseline. Cardiovascular events were observed in 3 women $(3 / 17,18 \%)$, obstetric complications were seen in 2 women $(2 / 17,12 \%)$, and fetal/neonatal events were seen in 3 infants $(3 / 17,18 \%)$ (table 1$)$. Median gestational age at delivery and birthweight were 38 weeks (24-39 weeks) and $2770 \mathrm{~g}$ (2195-3720g), respectively. Median RV end diastolic volume (EDV) was $119 \mathrm{~mL} / \mathrm{m} 2(85-214 \mathrm{~mL} / \mathrm{m} 2)$, stroke volume was $75 \mathrm{~mL}(57-138 \mathrm{~mL})$ and RVEF was $38 \%$ (30-51\%). RVEF was $\geq 35 \%$ in $10 / 17(59 \%)$ and $<35 \%$ in $7 / 17$ (41\%) women. Of those with $\mathrm{RVEF}<35 \%, 3 / 7$ (43\%) had a cardiovascular event. The median RVEF was 33\% (32-34\%) in those with a cardiovascular event compared with $38 \%(30-51 \%)$ in those without a cardiovascular event. There was a trend toward statistical significance for occurrence of cardiovascular events in women with RVEF $<35 \%(\mathrm{p}=0.051)$. Adverse obstetrical or fetal/neonatal events did not relate to decreased RVEF.

\section{Conclusions}

Impaired RVEF, specifically RVEF $<35 \%$ as determined by CMR, may be useful for stratification of risk for pregnancy-related cardiovascular complications in women post Mustard palliation. These preliminary findings require validation in a larger cohort of patients. 
Table 1 Summary of demographic characteristics and outcomes

\begin{tabular}{|c|c|}
\hline Maternal demographic data & $\begin{array}{r}\text { Median } \\
\text { (range) }\end{array}$ \\
\hline Age at Mustard palliation (years) & $2.2(0.6-6)$ \\
\hline Age at delivery (years) & $31(25-37)$ \\
\hline Age at CMR (years) & $32(27-37)$ \\
\hline Gravidity & n (\%) \\
\hline Gravida 1 & $5(31 \%)$ \\
\hline Gravida 2 & $3(19 \%)$ \\
\hline Gravida $\geq 3$ & $8(50 \%)$ \\
\hline \multicolumn{2}{|l|}{ Cardiac anatomy } \\
\hline Transposition of the great arteries with intact septum & $14(82 \%)$ \\
\hline $\begin{array}{c}\text { Transposition of the great arteries with ventricular septal } \\
\text { defect }\end{array}$ & $2(12 \%)$ \\
\hline Transposition of the great arteries with aortic coarctation & $1(6 \%)$ \\
\hline \multicolumn{2}{|l|}{ Cardiovascular events in pregnancy } \\
\hline Decline in NYHA classification & $1(6 \%)$ \\
\hline Sustained tachyarrhythmia resulting in heart failure & $1(6 \%)$ \\
\hline Cardiac arrest & $1(6 \%)$ \\
\hline \multicolumn{2}{|l|}{ Obstetric events } \\
\hline Premature rupture of membranes & $1(6 \%)$ \\
\hline Placental abruption & $1(6 \%)$ \\
\hline \multicolumn{2}{|l|}{ Fetal/neonetal events* } \\
\hline Premature delivery $<37$ weeks & $3(18 \%)$ \\
\hline Admission to intensive care unit & $4(24 \%)$ \\
\hline Death & $1(6 \%)$ \\
\hline *events not mutually exclusive & \\
\hline
\end{tabular}

\section{Funding}

None.

\section{Author details}

${ }^{1}$ Radiology, Sunnybrook Health Sciences Centre, Toronto, ON, Canada. ${ }^{2}$ Cardiology, Boston Children's Hospital, Boston, MA, USA. ${ }^{3}$ Radiology,

Toronto General Hospital, Toronto, ON, Canada. ${ }^{4}$ Cardiology, Toronto General Hospital, Toronto, ON, Canada.

Published: 30 January 2013

doi:10.1186/1532-429X-15-S1-P299

Cite this article as: Juan et al:: Relationship between cardiac magnetic resonance imaging parameters and pregnancy outcomes in women post mustard repair: a multi-center study. Journal of Cardiovascular Magnetic Resonance 2013 15(Suppl 1):P299.

\section{Submit your next manuscript to BioMed Central} and take full advantage of:

- Convenient online submission

- Thorough peer review

- No space constraints or color figure charges

- Immediate publication on acceptance

- Inclusion in PubMed, CAS, Scopus and Google Scholar

- Research which is freely available for redistribution

Submit your manuscript at www.biomedcentral.com/submit
C Biomed Central 